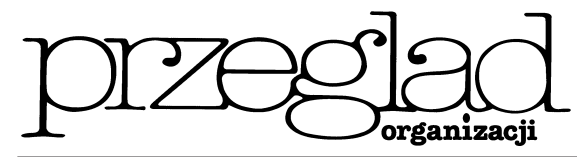

\title{
Dynamiczne aspekty organizacji
}

https://doi.org/10.33141/po.2005.05.03

\section{Marek Brzeziński}

\section{Wprowadzenie}

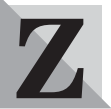

asadniczym celem nauk o zarządzaniu jest kreowanie określonych wzorców postępowania wynikających z ewolucji wiedzy teoretycznej i praktycznej, do których należy zmierzać, przechodząc stany pośrednie osiągane w rzeczywistych warunkach i w określonym czasie. W tradycyjnym podejściu dużą wagę przywiązywano do zasobów materialnych, co zdominowało sposoby myślenia odzwierciedlone np. w modelach matematycznych, traktujących elementy, podsystemy itp. w organizacji ,,jak rzeczy nieożywione" i łatwo przewidywalne [5]. Turbulencja otoczenia organizacji teraźniejszości powoduje, że coraz trudniej można stosować znane, rutynowe reguły postępowania. Wymusza to zastępowanie obowiązujących paradygmatów nowymi, które uwzględniać będą w nowoczesnych modelach organizacji procesy niezbędne w przystosowywaniu się do zmiennych warunków otoczenia.

Wydobywanie na światło dzienne nowych koncepcji i modeli organizacji, zawierających się pomiędzy teraźniejszością a przyszłością, może dać jaśniejszy pogląd na mechanizmy funkcjonowania systemów organizacyjnych oraz metody zarządzania nimi. W ramach umysłowej wędrówki ${ }^{1}$, po kolejnych wyzwaniach i skojarzeniach w naukach o zarządzaniu, następować będzie ujawnianie zjawisk kształtowania nowoczesnych organizacji. Przebudowa aktualnych podejść wymaga przewartościowania tego, co dotąd uznawano za obowiązujący stan rzeczy, poszukiwania nowych obrazów organizacji i modeli oraz całościowego zarządzania nimi. Aby pójść naprzód wykorzystamy systemowy i holistyczny sposób widzenia i myślenia o organizacji i zarządzaniu jako reguły badawczej tworzącej układ całościowy, oparty nie tylko na wiedzy na temat składowych modelu organizacji. Takie podejście uzupełnione będzie o metodę posługiwania się metaforą mózgu, organizmową, przepływu i transformacji [8] oraz metaforą zespolonego umysłu [1].

\section{Wyznaczniki dynamiki}

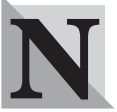

owe ujęcia uwzględniać muszą fakty, że każda organizacja, jej otoczenie, procesy rynkowe itd. są tworami niepowtarzalnymi, ,żyjącymi" dynamiką swojego wnętrza i dynamika relacji, wynikającą z współistnienia obiektów zanurzonych w większym systemie. W takim układzie nierównowaga zewnętrzna stymuluje zachwianie stanów oczekiwanej, wewnętrznej równowagi oraz permanentne procesy dążenia do osiągania względnej stabilności. Poszukiwanie nowych możliwości kształtowania modelu organizacji, adaptującego się do dynamiki zmian
Przegląd Organizacji, Nr 5 (784), 2005, ss. 13-15 www.przegladorganizacji.pl Towarzystwo Naukowe Organizacji i Kierownictwa (TNOiK) otoczenia i wypływajacych z interakcji otoczenia, wywoływana jest przede wszystkim przez rozmywanie się granic pomiędzy organizacją a otoczeniem ${ }^{2}$. Wtedy każdy element czy obszar organizacji należy jednocześnie do dwóch niejako dualnych stanów i systemów. Toteż indywidualne cele organizacji są przeważnie w konflikcie z celami otoczenia, gdyż otoczenie wymaga jednego, a organizacja oczekuje drugiego. Konflikt ten nie pozwala organizacjom i otoczeniu stanowić harmonijnej całości. Aby jednak organizacja mogła się rozwijać, musi ewoluować wraz ze swym otoczeniem, przez właściwą współpracę oraz wzajemność oddziaływań, w nietłumionym i zintegrowanym działaniu, w jedności i organicznej całości (rys.).

Organizacja czerpie $\mathrm{z}$ otoczenia użyteczne informacje, a po ich przetworzeniu kształtuje swoje procesy organizacyjne, wprowadzając określone zmiany, wpływające na systemy społeczny i informacyjny. A brak zewnętrznej harmonii przenosi się do wnętrza organizacji i wpływa na jej podsystemy, a nade wszystko na układ „człowiek-organizacja”, zawsze silnie związany z zarządzaniem. Organizacja więc jako system społeczny jest systemem dynamicznym, dzięki czemu może rozwijać się i funkcjonować w zmieniających się warunkach. Rozwój ten jest procesem, którego dynamikę można zinterpretować poprzez ujęcie integralne, zarówno warunków otoczenia, jak i samej organizacji. Wobec tego integracja trzech wyznaczników dynamiki, tj. „otoczenia-systemu informacyjnego-systemu społecznego”, określa pewien model przepływu i wymiany informacyjnej, który przebiega przez procesy i struktury organizacyjne, tworzac obraz dynamiki organizacji. Integracyjne mechanizmy doprowadzają więc do utworzenia informacyjnego pola organizacji, w którym wykorzystywane sa informacje i wiedza o całokształcie organizacji i jej zarządzaniu.

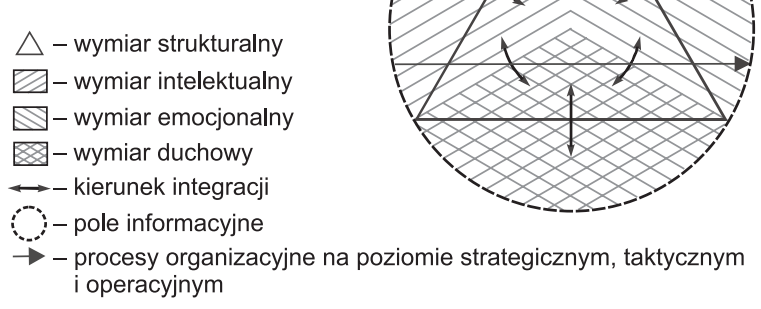
Rys. Integracja komponentów pola informacyjnego

Źródło: opracowanie własne.

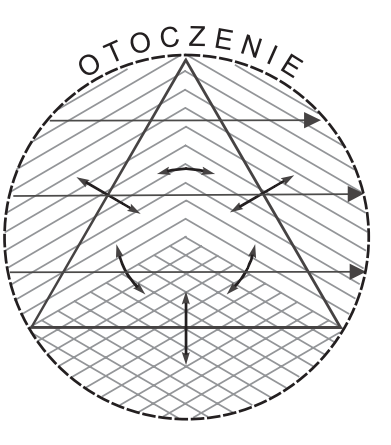




\section{Przez psychospołeczne wymiary organizacji}

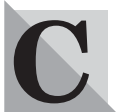

ałościowe postrzeganie układu „organizacjaotoczenie" ułatwia przepływy informacyjne pomiędzy nimi i ich integrację. Uważniej zwracając się ku otoczeniu, otwieramy się na model dynamiczny, w którym poszczególne podsystemy organizacji reagują na zbiory informacji pozyskiwane $\mathrm{z}$ otoczenia. Wtedy zacierają się wyraziste granice pomiędzy organizacją a otoczeniem, co ułatwia połączenie ich w jedną interaktywną całość (rys.). Procesy organizacyjne na wszystkich poziomach zarządzania odbierając informacje i wiedzę o otoczeniu i integrując ją z wnętrzem organizacji, zwiększają potencjał zawarty w niematerialnych zasobach indywidualnego i zbiorowego systemu społecznego. Dynamika zjawisk zachodzacych $\mathrm{w}$ systemie społecznym jest wyznacznikiem dynamiki systemu informacyjnego [3,10], a to $\mathrm{z}$ kolei determinuje dynamikę całej organizacji $[1,2]$. Wobec tego dynamika ta może się przejawiać $\mathrm{w}$ wymiarach odzwierciedlajacych istotę i naturę psychospołecznego aspektu organizacji.

Obecny w określonej strukturze organizacyjnej kapitał ludzki można odnosić do pracownika ${ }^{3)}$ i zbiorowości ${ }^{4)}$ (a więc zespołów i całej organizacji) oraz zachodzących tam procesów decydujących o funkcjonowaniu ,zespolonego umysłu organizacji”. Dlatego zachowania wyłaniające się zarówno z działań indywidualnych, jak i zbiorowych, obejmują następujące wymiary (plany) odniesienia:

- strukturalny - odnoszący się tutaj do jego dynamicznych aspektów, czyli oddziaływania i powiązań pomiędzy składowymi a zorganizowaną całością o charakterze informacyjnym, między dostawcą i odbiorcą informacji oraz ich przetwarzaniem itp.,

- intelektualny - indywidualne i zbiorowe procesy wykorzystujące potencjał tzw. inteligencji racjonalnej, czyli zdolności zdobywania i posługiwania się informacjami i uczenia się, umiejętności analizy i syntezy kreujące rozwiązywanie problemów i czynności poznawcze itp.,

- emocjonalny - indywidualne i zbiorowe procesy zawierające się w tzw. inteligencji emocjonalnej, czyli uczucia związane $\mathrm{z}$ atutami i słabościami, motywacją i twórczym napięciem, empatią i odczuciami współpracowników itp.,

- duchowy - indywidualne i zbiorowe potrzeby zawarte $\mathrm{w}$ tzw. inteligencji duchowej, czyli dążenie do głębokich i twórczych wartości, postrzeganie działań własnych i zespołowych w szerszym i bogatszym kontekście, poczucie przynależności do organizacji i potrzeba szczerej komunikacji itp.

Wymienione wymiary nie są same w sobie zupełne i stanowią tylko statyczną stronę obrazu organizacji. $\mathrm{O}$ dynamicznym jej wizerunku zdecydują dopiero interakcje pomiędzy tymi wymiarami oraz wpływy otoczenia umożliwiające traktowanie ich jako organicznej całości $\mathrm{i}^{5)}$. Uzyskują wtedy spoistość organizacyjną, poprzez system informacyjny integrujacy przenikające się obszary, drogi komunikacji itp. Dlatego wymienione już plany odniesienia nie funkcjonują w izolacji, ale poddają się naturalnej potrzebie zmniejszania rozbieżności pomiędzy sobą i łączenia się w całość, redukująca także wpływy otoczenia do bezpiecznego poziomu.
Przyczyny zaburzeń w systemie społecznym organizacji są pochodną zachwiania względnej równowagi, wynikającą z dominacji któregoś z wymiarów. Jednoczesna nierównowaga wszystkich obszarów spowodować może całkowity chaos w strukturze organizacyjno-informacyjnej ze wszystkimi tego konsekwencjami. Stany zaburzeń któregokolwiek wymiaru organizacji świadczą o stopniu nierównowagi w całym systemie organizacyjnym. Jeśli np. dotyczą one struktury, to mamy do czynienia z organizacją skoncentrowaną w dużym stopniu na hierarchiczności. W przypadku dominacji innego z wymiarów, organizacja ewoluuje $\mathrm{w}$ stronę niehierarchiczności. Umacniają się wtedy połaczenia, związane bezpośrednio z człowiekiem i zbiorowością, skłaniające się ku budowaniu organizacji opartej na zespołach [2].

W stworzonym polu informacyjnym ${ }^{6}$ ) zachodza prawdopodobnie zjawiska dotyczące przepływu informacji i wiedzy, jako regulatora wspólnej przestrzeni informacyjnej. Przepływające strumienie informacji kształtują wnętrze organizacji przyczyniając się do uzyskiwania określonej równowagi, co sprawia, że system społeczny i informacyjny są ważnymi wyznacznikami dynamiki organizacji. Teoretycznie rzecz ujmując, będą działać tutaj swoiste receptory równowagi, odbierające informacje wewnętrzne i zewnętrzne, spełniające rolę „błędnika równowagi” zwiększającego zakres wewnętrznej spójności organizacji.

\section{Ku dynamicznej równowadze}

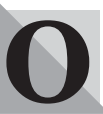

rganizacja, podlegając wpływom licznych czynników wewnętrznych i zewnętrznych wywołujących wielopłaszczyznowe zmiany o trudnej do określenia sile oddziaływania, stwarza nieprzewidywalną perspektywę funkcjonowania, szczególnie dla organizacji przyszłości oraz rodzi coraz więcej problemów utrudniających poruszanie się w nadchodzącej rzeczywistości. Dynamika otoczenia nabiera więc dużo większego znaczenia i wpływu na wnętrze organizacji, które również podlega „sprzężonej” ewolucji. Zatem dynamika organizacji staje się ważniejsza, aniżeli jej rutynowe reguły działania i stabilizacja. Trzeba więc położyć większy nacisk na osiąganie takiej równowagi w organizacji, aby uwzględniając dynamikę otoczenia wywoływać odchodzenie od potrzeby „doskonałości organizacyjnej” na rzecz dynamicznej równowagi.

Dynamicznej równowagi nie można zaplanować, gdyż jest ona naturalną i spontaniczną cechą systemu społecznego i całej organizacji, osiąganą w określonych warunkach i czasie. Zbliżanie się do stanu tymczasowej równowagi, w którym nastąpi równomierne rozłożenie czynników wewnętrznych i zewnętrznych, dokonuje się w czterech planach systemu społecznego, poprzez wzajemne oddziaływanie między pracownikami i łączącą ich zbiorowością, przy użyciu systemu informacyjnego oraz z uwzględnieniem dynamiki otoczenia.

Organizacje za pomoca systemu informacyjnego [10] osiągają swoją indywidualną i niepowtarzalną dynamikę, która zawiera się pomiędzy zmianą a stabilnością. Działania przebiegające w polu informacyjnym organizacji tworzą więc stale nowe formy dynamicz- 
nej równowagi. Taka równowaga może ujawniać się jako synergiczna energia w odniesieniu do pracownika, zespołów i całej organizacji, w postaci pobudzonych sił samoorganizacji i samorozwoju na wszystkich szczeblach zarządzania (strategicznego, taktycznego, operacyjnego).

Poszukiwanie dynamicznego wizerunku organizacji wymaga zastanowienia się nad istotą dwóch przeciwnych stanów, w których potencjalnie znajdować się może organizacja, tj. „choroby” i „zdrowia”. W teoretycznym ujęciu przez zdrową organizację najczęściej rozumie się taka, która nie jest w stanie choroby. W rzeczywistych warunkach nie jest oczywiście możliwe osiagnięcie stanu idealnego zdrowia, z uwagi na wpływ różnorakich czynników pochodzących z warunków zewnętrznych oraz wnętrza organizacji. Powstawanie choroby jest więc wynikiem połączonego oddziaływania obu rodzajów czynników, które napierając wywołują brak równowagi. Gdy mają one większą siłę oddziaływania niż siły im przeciwstawne, pojawiaja się symptomy zaburzeń - stanu choroby organizacji. Różnica pomiędzy dwoma stanami, zdrowia i choroby organizacji, rzutuje na filozofię, jaką należy kierować się w doskonaleniu cech organizacji sprzyjajacych funkcjonowaniu w trudno przewidywalnych warunkach.

Przy założeniu dominującej roli człowieka i zbiorowości pracowniczej, zaburzenia sa przede wszystkim wynikiem braku harmonii w psychospołecznych wymiarach organizacji. Dlatego, gdy pojawia się skumulowane objawy choroby trzeba rozpoznać, w którym z wymiarów plasują się czynniki je wywołujące, a więc jakie jest ich podłoże. Mimo że objawy odbijają się najczęściej na wszystkich planach, to trzeba odnaleźć praprzyczynę pierwotnego braku równowagi. Wtedy uzyskujemy lepszy obraz i wgląd w możliwości harmonizowania i przywracania dynamicznej równowagi organizacyjnej i zastosowania określonych sposobów dotyczących tego wymiaru, w obszarze którego odnaleziono praprzyczynę wzbudzającą nierównowagę. Będą to metody jednorodne z tym obszarem, które poprzez ich podobieństwo umożliwią regulację tego obszaru oraz przeniesienie pozytywnych skutków naprawczych do pozostałych wymiarów całościowej organizacji.

W przyjętym podejściu, inaczej niż w tradycyjnym ujęciu, dążymy do przywrócenia równowagi poprzez uruchomienie w organizacji naturalnych sił samoharmonizacji, doprowadzających do osiagania stanu zdrowia całego systemu. Będą one miały modelujący wpływ na usuwanie przeszkód, które $\mathrm{z}$ powodu zaistnienia pierwotnej nierównowagi pojawiły się we wszystkich głównych mechanizmach samoregulacji. Pobudzą więc zdolność organizacji do nasilania się procesów osiagania ponownej równowagi na nowym poziomie, odpowiednim dla określonej sytuacji i pomogą odbudować wyższą jakość systemu zarządzania.

Neutralizowanie skutków oddziaływania negatywnych czynników odbywa się poprzez system informacyjny niezbędny do harmonizowania i integrowania funkcji naprawczych. Dlatego osiaganie i następnie utrzymywanie naturalnej, dynamicznej równowagi zależy w dużej mierze od symultanicznego przetwarzania informacji na potrzeby utrzymania zrównowa- żonego stanu zdrowia organizacji. Oczywiście choroba organizacji nie musi wykluczać jej zdrowia. Wręcz przeciwnie, może ona uzmysławiać nowe możliwości organizacji, wobec których stają się one procesem twórczym, zmieniającym kolejne stany pośrednie „od choroby do dynamicznego zdrowia".

dr hab. inż. Marek Brzeziński profesor Politechniki Lubelskiej

PRZYPISY

1) „Prawdziwie odkrywcza podróż polega nie tylko na szukaniu nowych krajobrazów, lecz na spojrzeniu nowymi oczami" - Marcel Proust.

2) Współczesne organizacje wraz ze swoim otoczeniem staja sie megaorganizacjami bardzo silnie zawłaszczajacymi i przenikającymi dużą część otoczenia. Nadążanie za zmianami w tak skomplikowanej całości wywołuje napiecia, które mogą dzielić, ale mogą też łączyć i przybliżać relacje "organizacja-otoczenie”, wyzwalając dodatkową energię rozwojowa.

3) $\mathrm{W}$ odniesieniu do człowieka integracja obejmuje następujace wymiary: cielesny, intelektualny, emocjonalny i duchowy. Przedstawia je I. MAJEWSKA-OPIEŁKA [6], psycholog zarządzania i doradca firm w Stanach Zjednoczonych i Kanadzie. Ważne odkrycia ostatnich lat dotyczace tzw. inteligencji emocjonalnej i duchowej odnajdziemy np. w pracach $[4,7]$.

4) Dla zbiorowości istnieje pojęcie tzw. umysłu zbiorowego $[3,9,11]$, pozwalające na określenie myślenia i działania zbiorowego oraz ich dynamiki zachodzącej w systemach informacyjnych [10]. Uzupełnieniem tej problematyki jest koncepcja „zespolonego umysłu organizacji” [1], która posłużyła do opracowania modelu w formie „kreatywnej organizacji" [2].

5) Zaprzeczanie istnieniu któregoś z nich, co zdarza się w tradycyjnym podejściu do organizacji i zarzadzania, stanowi niebezpieczeństwo fragmentarycznego, a nie holistycznego traktowania funkcjonowania organizacji. Te wymiary przeplataja sie ze soba i nawzajem uzupełniaja oraz prowadzą do rozwoju coraz większych fragmentów indywidualnego i zbiorowego potencjału systemu społecznego w organizacji.

6) Etymologiczne korzenie słowa „informacja” wywodzą się od łacińskiego czasownika informare, który oznacza wewnętrzne formowanie.

\section{BIBLIOGRAFIA}

[1] BRZEZIŃSKI M., Koncepcja organizacji przyszłości, [w:] Przedsiębiorstwo przyszłości - nowe paradygmaty zarzadzania europejskiego, red. nauk. I.K.HEJDUK, ORGMASZ, Warszawa 2003

[2] BRZEZIŃSKI M., Inżynieria kreatywnej organizacji, „Ekonomika i Organizacja Przedsiebiorstwa” 2004, nr 8.

[3] EDEN C., SPENDER J.C., Managerial and Organizational Cognition. Theory, Methods and Research, Sage Publications, London 1998.

[4] GOLEMAN D., BOYATZIS R., MC KEE A., Naturalne przywództwo, Wydawnictwo Biznesowe, Warszawa 2002.

[5] HATCH M., Teoria organizacji, Wydawnictwo Naukowe PWN, Warszawa 2002.

[6] MAJEWSKA-OPIEŁKA I., Umyst lidera. Jak kierowac ludźmi u progu XXI wieku, Wydawnictwo MEDIUM, Warszawa 1998.

[7] MARCIC D., Managing with the Wisdom of Love, Jossey-Bass Publishers, San Francisco 1997.

[8] MORGAN G., Obrazy organizacji, Wydawnictwo Naukowe PWN, Warszawa 1997.

[9] SIMON H., Administrative Behavior: A Study of Decision Making Processes in Administrative Organizations, Free Press, New York 1997.

[10] UNOLD J., Dynamika systemu informacyjnego a racjonalność adaptacyjna, „Monografie i Opracowania” nr 154 Wydawnictwo Akademii Ekonomicznej we Wrocławiu 2003. [11] WHEATLEY M.J., Leadership and the New Science. Discovering Order in a Chaotic World, Berrett-Koehler Publishers, San Francisco 1999. 